\title{
Border Economies of the Middle East: Why do they matter for political economy?
}

\begin{abstract}
Although borderland regions of the Middle East and North Africa represent active sights of economic and social exchange, they remain peripheral to the analysis of the region's political economy. Conventional accounts of cross-border informal trade tend to emphasize its illegality based on existing economic regulations, overlooking the deep political foundations of such trade. This article posits new arguments on the political economy significance of cross-border informal trade in the Middle East, highlighting its relevance for studying processes of state formation, durability of authoritarian regimes, conflict, informal institutions and the interdependence between domestic and external political economy domains. Our analysis underscores the need for a more holistic understanding of border economies that moves the field away from a security-centred view that treats such trade as mainly a law and order issue.
\end{abstract}

\section{Keywords}

Smuggling, informal economy, political economy, Middle East

\section{Acknowledgements}

The authors would like to thank Grace Fussell for her assistance with maps in this paper, and three anonymous referees for their constructive suggestions that greatly improved the paper. This work was sponsored by the Economic Research Forum (ERF) and has benefited from both financial and intellectual support. The contents and recommendations do not necessarily reflect ERF's views. 


\section{Introduction}

"Smuggling...has always been political—and, because of its extent and interconnectedness, geo-political. In other words, it has been a key factor in international relations, conflict and globalization".

— Harvey (2016: p. 10)

It has become customary to situate many of the Middle East's contemporary ills in the history and politics of its border making. References to the epochal Sykes-Picot agreement and the arbitrariness of physical boundaries between Arab nations echo in discussions across the political spectrum and academic writing. The region's contemporary borders represent one of its most important historical continuities (Rogan 2016). The fixity of these borders coexists with the fluidity with which informal economic exchange criss-crosses national boundaries. As Middle Eastern borders have been increasingly problematized, their political economy, rooted in their porosity to the informal flow of goods, has been largely overlooked.

Although traditionally caricatured as a region with thick economic borders, where the official flow of goods is severely restricted through an array of arbitrary trade barriers, the Middle East's border regions remain active zones of informal economic exchange. They feed into transnational trade networks, sustain border communities, define limits to state autonomy and shape economic and political power. However, the importance of such border exchange is typically recognized only in times of crises or political upheavals. The chaos in Tunisia's border regions following the overthrow of Ben Ali in 2011 and the civil wars in Libya, Syria, and Iraq have resuscitated interest in understanding how rents from informal trade feed into violence. ${ }^{1}$ Given the context, it is unsurprising that informal border exchange is frequently treated as a law and order issue - an aberration or departure from the norm. ${ }^{2}$ But can smuggling simply be controlled by monitoring borders and ensuring better enforcement? And, if so, what explains the puzzling persistence of cross-border 
informality in the face of stronger policing? Why has it endured through periods of crises, civil wars, and policy shocks (e.g., trade liberalization)?

This article calls for the need to reconceptualize the border economies of the Middle East and North Africa (henceforth, MENA) in terms of their central significance for the region's political economy. ${ }^{3}$ To this end, we develop four inter-related strands of arguments. First, we show how border economies can enrich our understanding of larger objects of study, such as processes of state formation and the durability of authoritarian regimes. Cross-border informality typically emanates from restrictions on formal economic activity, such as monopolies and high tariff barriers, and restrictions induced by geopolitical shocks such as sanctions and wars. Rents generated through border economies can be politically consequential, as they benefit not just the local handlers of such trade but also enrich ruling elites and their entourage whose support is crucial for regime survival and stability. At the same time, borders assume additional political significance in a region where welfare entitlements are a central component of authoritarian bargains. They demarcate the geographic boundary of entitlements, while at the same time creating spaces where illegal trade is tolerated as the primary means of subsistence for communities that have faced persistent neglect from central development planners.

A second related argument presents border economies as domains of both cooperation and conflict and thereby central to understanding the political economy of conflict. Frontier regions were often the weakest points of empires, defining the limits of their sovereignty, exclusivity and control. Ottoman borders, which were "broad, porous, and impermanent" (Meir 2016, p. 19), have long represented sites of "rebellion and resistance" (p. 20). As ongoing civil wars in the Middle East show, rents from smuggling feed into war economies that, in turn, have profound impacts on the political economy of these states. We show that smuggling-induced war economies display strong continuities with pre-war institutional orders and norms, thereby offering an important mechanism of institutional persistence. At the same time, they offer crucial information about factors that intensify and prolong conflict and shape the trajectory of post-conflict political economies. 
Third, we argue that the analysis of cross-border informality can offer crucial markers for many bread and butter issues of political economy. As an exemplar of personalized exchange, border economies support a dense web of relationships, undergirded by social norms, religious beliefs and local conventions, and help to elicit cooperation and trust. It is precisely due to these historically embedded and socially anchored relationships that borderlands are useful laboratories for studying the role of informal institutions in development and their interplay with formal institutions - the police, judiciary, and the institutional incentive structure that governs economy and polity - in line with the research agenda on informal institutions proposed by Helmke and Levitsky (2004). ${ }^{4}$

Our fourth argument highlights the role of border economies in revealing the interplay between internal and external factors in ways that is both complex and consequential for the region's political economy. Border economies highlight the importance of regional complementarities and linkages, and demonstrate how institutional challenges in one country are increasingly interlinked with challenges in neighbouring jurisdictions. Here, an analysis of border economies will not only help the study of the MENA political economy overcome its frequent methodological nationalism, but also contribute to central discussions in international political economy (henceforth, IPE), such as the changing regulatory capacity of states in the context of globalisation, the effects of sanctions and trade barriers, and the political economy of reconstruction.

Despite its central importance for the region's political economy, holistic analyses of Middle East's border economies remain a largely unexplored research territory. Economic work on smuggling in the region has primarily focused on developing novel methodological tools to estimate its scope (Bensassi et al. 2015; Ayadi et al 2013; Farzanegan 2007). Although there is no region-wide estimate for the size of informal border trade, country-level studies indicate that such trade is both sizeable and significant across the region. ${ }^{5}$ Scholarship on the Middle East politics has produced insightful studies of urban informality (Assaad 1993; Bayat 1997; Elyachar 2005) but has not adequately explored the border dimension. 
Recent years have seen a growing literature on MENA border economies from historical and anthropological perspectives (McMurray 2001; Laroussi 2013; Meddeb 2012; Soto Bermant 2015; Hüsken 2018; Ellis 2018). However, with the exception of Gallien (2019), this literature only engages with the phenomenon's political economy dimension in passing. In parallel, the dominant literature on MENA political economy completely sidesteps the region's border economies. Standard texts on Middle Eastern political economy such as Richards and Waterbury (2007), Ayubi (1996) or Milton-Edwards (2018) provide no systematic discussion of the issue. Analyses of business-state relationship in the Middle East have also focused almost entirely on interactions between the state and "formal" businesses, neglecting the significance of informal commercial networks operating in borderland regions (Heydemann 2004; Hertog, Luciani, and Valeri 2015). Our primary contribution in this paper is to raise the curtain for an important but understudied subject and to offer concrete signposts for ways in which cross-border informality can enrich the study of the political economy of MENA.

The rest of this paper is organized as follows. Section 2 briefly maps cross-border informality across key informal trade corridors as a backdrop to our main analysis. Section 3 develops our central argument on the political economy significance of border economies. The discussion is divided into five sub-sections dealing, respectively, with issues of state formation, regime resilience, war economies, informal institutions, and regional interdependence. Section 4 concludes.

\section{Mapping MENA's border economies}

In this section, we briefly describe the salient features of MENA's border economies that are essential for appreciating their political economy significance. We define cross-border informality in the broadest sense possible as consisting of all cross-border trade that does not conform to existing trade regulations. Such trade can pass through official border posts unnoticed, or be noticed but unregistered and not taxed (commonly in exchange for a bribe). It can also bypass official border posts altogether and can be conducted by firms with official business and trade permits or by unregistered and untaxed informal agents. Many studies differentiate between goods traded illegally — the most common distinction being between licit and illicit goods, typically 
distinguished depending on whether or not a legal trade corridor for these goods exists. Examples of illicit goods include narcotics, counterfeit medicine, and arms.

Our objective is to highlight the considerable variation in patterns of informal trade and the key parameters useful for mapping this heterogeneity. We focus on three crucial dimensions: the types of goods traded and their associated corridors, the principal drivers of cross-border informality, and the nature of actors involved in such trade.

Goods. - Although precise estimates are lacking, oil is the most important informally traded item in the MENA region, in terms of its dollar value, the number of people involved, and its regional spread. Active corridors for this trade include the borders of Algeria (with Morocco, Mali, Tunisia), Libya (with Tunisia, Egypt, Niger, Malta, Italy), Iraq (with Syria, Turkey), and Iran (with Afghanistan, Iraq, Turkey). Gasoline is being traded by a wide variety of formal and informal actors, and is usually sold in small informal roadside gas stations that can be found across the region, but can also function as a direct input to agriculture or industry. Figure 1 outlines the main corridors for the illegal trade of gasoline and crude oil in the region, as well as the respective pump price for gasoline in 2016. The gasoline trade is subjected to temporal shifts influenced by changing events on the ground, especially in war-torn Iraq, Syria, Libya, and Yemen. In recent years, the fortification of the Morocco-Algeria border has substantially decreased the gasoline trade, while the unrest in Libya has affected informal trade with Egypt and Tunisia. The map represents a stylised picture. The corridors differ in the quantity of the gasoline traded, and their consequent impact on local populations.

[Figure 1 here]

Besides oil, a variety of consumer goods are traded informally in the region, including construction materials, electronic goods, household items, cigarettes, and clothes. Many of these goods originate in China and SouthEast Asia and are embedded in transnational networks of informal trade. Key corridors are the borders of Spain 
(with Morocco); Algeria (with Mali and Tunisia, until recently with Morocco); Libya (with Tunisia, Egypt, and Sudan). Ports that enjoy low tariff regimes or are connected with free trade zones play an important role in connecting these networks to global supply chains. While such trade also involves local small-scale actors, it typically relies on traders who are deeply embedded in international trading networks. These may include intermediaries in neighbouring countries, financiers elsewhere in the region, and closely connected suppliers half-way across the globe.

The informal trade of food items ranges from representing a small additional income for farmers in border regions to sustaining the livelihoods of large communities in connected territories. The main goods traded are staple items, such as wheat, pasta and milk powder, as well as meat, livestock, dates and other fruits. Processed food items are often traded due to price differences and subsidies, while the illegal trade of local produce allows farmers to evade the control of marketing boards or capitalise on a larger market. Such trade clearly serves a crucial purpose in a region that is heavily dependent on food imports. It is difficult to imagine, for example, how the food requirements of Northern Mali or of the Gaza strip could be met without such informal trading possibilities. ${ }^{6}$

The main corridors for the smuggling of non-gasoline consumer goods are mapped in Figure 2 . This is clearly a sparse representation, as we only highlight the most important corridors. One crucial caveat is that the map focusses on smuggling across land borders, in line with the focus of this article. Nevertheless, even this limited mapping of land corridors highlights the MENA region's insertion into global trade corridors, particularly those involving China. It also underscores the role that sanctions and trade restrictions play in incentivising smuggling, a point we discuss more substantially below.

[Figure 2 here]

While not a primary focus of this study, a brief mention of the informal trade of illicit goods is important to complete the picture. The most frequently traded illicit goods are drugs, both for consumption within the region, and export to Europe. Cannabis produced in Lebanon or Morocco is smuggled into Europe and 
neighbouring MENA states for domestic consumption. Cocaine, usually shipped to West Africa from Latin America, follows a similar route, while synthetic drugs such as Tramadol and other prescription medicines have developed a sizeable consumption market within the region. The Levant, in particular, has seen a rise in the production of captagon, an amphetamine increasingly associated with the region's war economies. Domestic restrictions on alcohol have given rise to a significant liquor smuggling market, with large amounts going into the Arabian Peninsula and Iran, as well as out of wine-producing countries such as Morocco and Tunisia. ${ }^{7}$ Furthermore, smuggling of firearms has received intense public attention and is intensified by recent civil wars with the borders of Libya, Syria and Iraq serving as fertile grounds for this trade.

Figure 3 maps two key illicit goods traded in the region: cannabis and cocaine. The map illustrates the region's role as a transitional market, with large corridors stretching into Europe. However, this should not obscure two other functions of MENA in this trade. First, several MENA states are large producers of narcotics: Morocco and Lebanon for cannabis, and Iran for opiates. Second, the region has itself become an important consumer of drugs. A key lesson is that different goods have distinct and diversified networks and corridors. While the political discourse tends to conflate and generalise these different flows, any analysis of smuggling in the region needs to begin by highlighting the differentiated dynamics at play in different corridors and to identify the key drivers and actors of these trades.

[Figure 3 here]

Drivers.-Economic policies such as subsidies, tariffs and establishment of monopolies, make smuggling profitable. State-imposed limitations on trade, whether through border closures or sanctions, also drive crossborder informality. While there is considerable research on subsidy regimes in the MENA region, it has paid little attention to the connection between subsidies and the growth of informal trade. While energy remains heavily subsidized, there are noticeable price differences between bordering states, which incentivizes smuggling of gasoline. As Figure 4 shows, the margins for such arbitrage are substantial. Subsidy-induced 
informal trade of oil is rife in Libya, Algeria, Iraq, Saudi Arabia and Iran. Fuel smuggling influences the costs and consumption of gasoline in neighbouring states: in Tunisia, a small and oil-poor country between two hydrocarbon giants, the World Bank estimates that in 2014 more than 25\% of domestic gasoline consumption was made up of illegally imported petrol (Ayadi et al 2013).

[Figure 4 here]

Regional variation in food prices, driven by subsidies, also stimulate informal trade in food items. Apart from subsidies, domestic monopolies and exclusive export and import licences commonly generate significant price variation among neighbouring economies. Informal trade in consumer goods is primarily induced by variation in tariffs, particularly between neighbouring countries (tariff dispersion), and by attempts to evade tariffs altogether (tariff avoidance). Tariff differences are the principal driver of informal trade in non-food consumer goods, such as car parts, microwaves, clothes and household items.

North Africa's location as a connecting node between Europe and Africa also makes it part of larger trade corridors. Migrants and narcotics both make their way from sub-Saharan Africa to Europe, bypassing through North Africa. Besides situating these borders in a wider regional geography, it is also important to position them within the domestic political geography, and observe how centre-periphery relationships affect such trade. These processes are also commonly in a state of flux, following trends in global prices, or domestic political changes.

Actors.-Supply chains supporting informal trade are often dense and multi-layered, involving numerous actors with differential bargaining powers. Figure 5 illustrates one such diverse net of actors involved in the smuggling of carpets from East Asia into Tunisia. Relationships with other traders, brokers, or security forces can confer distinct advantages to the trader, including protection against predation, insurance against uncertainty, information and access. For example, a privileged relationship with a trader across the border 
might ensure exclusive access to certain goods. Similarly, having closer ties with police and border officials can be leveraged against other traders. Relationships with social brokers, such as tribal chiefs, can afford greater protection against uncertainty, while connections with other local traders might help to exploit and expand market power. It is the relative strength of these relationships that shapes the differential power of these actors, barriers of entry to trade, the concentration of local political and economic power, and the wider political economy of borderlands. Beyond these power dynamics, these relationships have a profound impact on the everyday life of border regions, since they shape the ease of access and employability in these trades, accumulation of capital, and the livelihoods of border communities. This brief overview of goods, drivers and actors of cross-border informality provides the necessary backdrop for our main arguments on the political economy significance of border economies in the following section.

[Figure 5 here]

\section{Political economy significance}

Whether conceived of as an alternative trading field of petty traders, atomized informal economic agents or a network of powerful brokers seamlessly operating on different sides of the border, the informal border economy lends a fascinating window into the prevailing hierarchies of governance. In fact, it will not be wrong to argue that smuggling and statecraft are inherently interconnected. We suggest that legal institutions and their evasion should be considered together, since they emanate from the same political domain. They both reflect and constitute the organization of political and economic power on the periphery and its relationship with centralized states of the region.

To highlight the political economy significance of MENA's border economies, we divide our discussion into four inter-related arguments. First, we start by establishing the significance of border economies for understanding the central and larger objects of analysis in contemporary MENA political economy scholarship, 
including state formation and regime durability. Second, we demonstrate how border economies provide a critical dimension to analyses of war economies and their continuity from pre-war institutional orders, and how this could, in turn, enrich the political economy literature. Our third argument presents cross-border informality as a particularly fertile ground for studying the role of informal institutions. Fourth, we demonstrate how border economies emphasize the regional interdependence between different national jurisdictions, thereby blurring the distinction between domestic dynamics and external factors. In developing these arguments, we draw on illustrative evidence from across the region, substantively engage with dominant literatures in the field, and highlight the specific insights that the study of border economies can offer to analyses of MENA political economy.

\subsection{State formation}

To the extent that cross-border informality defies the regulations of neighbouring political jurisdictions, it has been framed as a threat to national sovereignty ${ }^{8}$, the state's territorial integrity, its security and fiscal capacity (Hanlon and Herbert 2015; Dauvergne 2004; Boone 1994; Ayadi et al 2013) ${ }^{9}$, and directly associated with the debate on 'failed states'. ${ }^{10}$ These concerns imply the notion of a state that, at some point in history, entirely controlled its borders and diligently collected trade revenues. However, there is good reason to believe that this was rarely the case. Instead, we argue that the role of borderlands in state formation in the MENA region needs to be more consciously considered in analyses of the region's political economy, and that they can provide important clues about the very nature of the Middle Eastern state - and the limits of its sovereignty, the social contract it fosters with citizens, and its economic and political jurisdiction.

In the region's history, borderlands are spaces where markets and states are co-constituted. Both within history and anthropology, recent years have seen the development of a sizeable literature on the sociology of bordermaking in the Middle East. While a full discussion of this will go beyond the scope of this section, we highlight three historical moments in which the making of the contemporary Middle Eastern states interacted with their 
border economies, and which we see as under-appreciated in the relevant political economy discussions. These include: the establishment of the territorial state in the region, its political re-structuring in early independence years, and subsequent economic reforms in the 1970s and 1980s.

Trade in the MENA region predates borders. Naturally, the history of informal cross-border trade in the region goes hand in hand with the construction of both its states and borders. While the narrative of arbitrary colonially imposed borders in the Middle East through the 1920 San Remo conference has been widely recognized, historical accounts of border-making in the region also highlight the porosity and slow construction of de facto borders in the region. In this regard, merchant and tribal communities in borderland regions fulfilled a dual function. On the one hand, they saw their trade routes now crossing new political jurisdictions, facing tariffs or taxes, and seeing traditional routes transformed and diverted. On the other hand, as states were slow to expand their reach across their territory (Brandell 2006), local communities also served as crucial intermediaries and negotiators of state power (Meier 2018; Anderson 1987; Migdal 2008).

Two recent accounts of the Awlad Ali tribe in the borderland between Libya and Egypt, discussing their relationship with the central Egyptian state in the $19^{\text {th }}$ century (Ellis 2018), and in the late $20^{\text {th }}$ century (Hüsken 2018), highlight the continuity of these relationships into the modern era. Informal border economies emerged together with the modern state system, creating new opportunity structures and path dependencies, with their porosity and degree of state control remaining uneven and continuously in flux (Schayegh 2017; J. Scheele and McDougall 2012). While some scholars have highlighted ideological challenges that pan-Arab and Islamist movements posed to the system of states and borders in the region (Zartman 2017; Cassarino 2017), borderlands should also be approached as spaces where the state can be 'reshaped in its margins' (Raeymaekers 2012) through negotiations around regulatory power, rent streams and selective porosity.

Uneven state-building continued in the post-independence years through a difficult dialectic between the spatial projection of state power and the selective distribution of resources. The political economy literature 
discusses two central elements of post-independence state-building: clientelistic distribution of rents and provision of subsidies to citizens. Both have been shaped by, and had profound effects, in turn, on informal trade activity in border regions. Clientelistic ties with key groups within the merchant class ensured that economic spoils were monopolized by elites usually located in the political centre (Heydemann 2004). While this occurred, in part, at the expense of formal economic development in borderland areas, it often coincided with informal arrangements that tolerated the continuation of income-generating activities through informal cross-border trade (Gallien 2018). This dual relationship is most visible in the resource-scarce economies in North Africa and the Levant, which, unlike their rich Gulf neighbours, had limited state resources to appease elites in the periphery.

Post-independence state-building efforts also involved putting in place a generous welfare regime that cemented ties with the general citizenry through subsidies on gasoline and food items (Eibl 2019). While largely aimed at including citizens in the new social pact, such welfare provision also had distinct effects on borderland regions. The disparities in subsidy provision between neighbouring states and the trade barriers resulting from import-substitution policies generated new arbitrage opportunities that incentivised informal trade. The 1970s oil boom increased the scale of these subsidies and the resulting price distortions that created arbitrage opportunities with neighbouring jurisdictions. The observation that the effects of oil rents in the region went beyond major oil-producing countries is well-established in the political economy literature (Malik 2017). However, the specific role that borderland networks play in this is commonly overlooked. Border economies are both a result of and a crucial constituency for the uneven landscape of economic distortions, subsidies, tariffs and heterogeneous institutional regimes in the region in the post-independence years. They represent a further segmentation—another 'legacy of dualism' (Assaad 2014) of Middle Eastern economies.

Another major historical juncture that affected the ecosystem of informal border trade was the post-1980s period that witnessed the initiation of neoliberal economic reform programmes in many countries. Even as trade tariffs were liberalized and key economic sectors were deregulated there is little evidence to suggest that 
informal trade decreased as a result. The resilience of informal trading activity to such trade policy shifts was partly attributable to selective trade liberalization, which meant that although tariffs fell on average there was wide dispersion across sectors. Sectors with politically connected actors continued to benefit from high levels of trade protection. At the same time, falling tariff barriers were typically accompanied by increasing nontariff measures, further entrenching border economies (Eibl and Malik 2016).

Effectively, selective liberalization preserved trade protection for politically connected sectors while perpetuating opportunities for arbitrage along the border. ${ }^{11}$ Alongside this, the role in employment generation vacated by a retreating state and changing agricultural sector in the wake of economic liberalization was often filled by the informal economy rather than the formal private sector. This further deepened the role of the latter in the changing social contract. ${ }^{12}$ As the state and its elites retained their control over key access points to the economy, the private and parallel economies became fundamentally inter-connected. ${ }^{13}$ The resilience of informal trade in the face of trade liberalization is also related to the changing architecture of global trade, signified, in particular, by falling transport costs, the penetration of cheap manufactured goods from East Asia, and China's growing competitive edge in global markets. The endurance, and, in some cases, growth, of informal trade networks in the face of major historical shifts, points to long-run continuities in the configuration of economic and political power in the periphery. It reflects the ability of these trade networks to adapt and forge new connections within and outside the region.

\subsection{Rents and political order}

Border economies can furnish important insights into a central empirical and theoretical puzzle: the exceptional durability of authoritarian regimes in MENA (Diamond 2015; Bellin 2004). To understand authoritarian resilience in MENA, mainstream political economy scholarship has offered three main explanations: the role of oil (Ross 2015), business-state relationship (Heydemann 2004; Haddad 2012; Hertog, Luciani, and Valeri 2015) and the nature of social pacts (Schlumberger 2007). These dominant explanations, however, have paid 
insufficient attention to the role of cross-border informality in explaining regime durability. While an analysis of border economies would not supplant existing explanations for regime durability, it significantly nuance our understanding and point to hitherto understudied mechanisms. To this end, we present below three salient dimensions. Firstly, while it is recognized that rents generated through economic protection can create "binding commitments" for elites and ensure that their interests are aligned with regime continuity (North, Wallis, and Weingast 2009), the full implication that rents generated by border economies can have on political equilibriums remains poorly explored. Here, we argue that rents from smuggling can be politically consequential. Secondly, border economies can be particularly important in sustaining authoritarian regimes through tough times, such as in the face of domestic and external shocks. Thirdly, we argue that informal trade is a central component of social pacts between MENA states and citizens and elites in the periphery, contributing to both stability and state control in their borderlands. We substantiate these arguments through concrete illustrations from the Levant and North Africa.

Consider a trade tariff that creates at least three different rent streams in the context of informal trade: one for the formal politically connected business deriving monopoly rents; another for the informal agent who extracts rents from the tolerated subversion of this trade regime; and a third rent stream appropriated by officials responsible for enforcing the tariff. Other rent-seeking intermediaries could include actors who negotiate the uncertainty of this economic domain by 'protecting' property rights through violence or by mediating access to state officials. In section 2, we discussed the central role of trade restrictions and domestic monopolies in driving informal trade. That such rents serve an important political function is well-recognized in the literature on hybrid governance and informal trade across the African borderlands but remains under-appreciated in the Arab context. ${ }^{14}$ While trade barriers (e.g. tariffs and non-tariff measures) often protect regime cronies (Eibl and Malik 2016), the strategic toleration of informal actors who surpass these same regulations can also elicit support or at least acquiescence from border constituencies. This allows regimes to support two types of constituencies with one policy tool. As Parker and Moore $(2007,10)$ note in the Iraqi context: "In tandemformal, state-regulated trade on top and tolerated local smuggling at the bottom - tied Iraq to its neighbours in 
politically consequential ways". Smuggling is thus an important part of the dualistic economic structure that Ragui Assaad situates in the region's authoritarian bargains (Assad 2014).

However, smuggling rents do not just accrue to actors in borderland regions. In Tunisia, smuggling provided an additional source of rents for the clan of former president Ben Ali (1987-2011). The President's family was well-inserted in informal trade networks, supporting the creation of monopoly rents for his wife's family and the associated network of connected businesses who were given exclusive control over the trade of certain items (e.g., bananas, dried fruits, nuts) ${ }^{15}$ in both formal and informal trade. In the formal realm, this was achieved through the manipulation of policy regulations and their enforcement. ${ }^{16}$ In the informal domain, this was managed through their influence over customs officials and direct co-operation with smuggling networks. As a result of this control, opportunities for smugglers in borderlands expanded with the fall of the Ben Ali regime in 2011. In several MENA states, elements of military and security services are also able to dip into these rents. In Syria, for example, Rifaat al-Assad, the former head of defence and uncle of current President, was known to be a key patron of this thriving black market afforded by the Lebanese intervention in 1976 and smuggling rackets across the Turkish border in the 1980s. ${ }^{17}$ The smuggling of cigarettes and cars were believed to have enjoyed the protection of the Syrian military and intelligence services (Haddad 2012).

Apart from generating rents for political insiders, border economies also lend regimes greater resilience in the face of economic and political shocks. Syria's half-hearted attempts at economic reform, triggered by the foreign exchange and liquidity crises in the 1990s, were a major boon for cross-border informality since the resulting loss of rents necessitated a stronger parallel economy where state officials and regime insiders could do business through their frontmen. It afforded the backdoor entry of many state officials and connected families into vast smuggling networks operating along the country's borders with Turkey and Lebanon (Haddad 2012, p 83). Competition for control over these economic networks has been a persistent feature of Syria's economy that was based on an internal division of spoils for members of military, bureaucracy and Baath party officials who, in turn, served as protectors of smuggling networks. Some of these informal 
networks came to the regime's rescue during the civil war - to navigate through the conflict, the regime redeployed these networks and negotiated agreements with opposition groups to clear the passage of goods across conflict lines. As Heydemann argues, the ability to tap into smuggling networks gave the regime "flexibility" to "outbid" the opposition and create new intermediaries who were loyal and dependent on the regime (Heydemann 2018, 58).

Cross-border informal trading networks also hold the key to understanding how Iraq under Saddam Hussain managed the dislocations induced by sanctions and war. In the face of receding state authority and substantially weakened capacity for rent distribution, the Iraqi regime relied on multiple competing economic jurisdictions where "transnational trade networks and a globalized sanctions regime came together to create new economic opportunities" (Parker and Moore, 2007, p. 8). Historically embedded connections with tribal sheiks in frontier regions were carefully managed to create new relationships based on rent-sharing arrangements. Meanwhile, businesses in neighboring countries formed a partnership with Iraq's Republican Guards to "facilitate and protect networks of transport and distribution" (Ibid., p. 8). By affording greater decentralized control over cross-border networks of exchange to rural elites and security officials, the regime was able to generate cooperation-contingent rents that both elicited the support of these elites and ensured the everyday citizen needs for survival. Simultaneously, these exchange networks supported the emergence of new actors enjoying strong ties to rural clans and inserted in cross-border exchanges with Turkey, Jordan and Iran. In short, Iraq's frontier economic zones became crucial sites for regime survival during the sanctions era and afforded the Iraqi regime a greater room to manoeuvre in the face of external shocks.

Cross-border informality can also form an essential component of the regime's social pact, whereby illegal economies are tolerated as a concession to communities in the periphery who, in the absence of state provision, look towards informal sector employment and affordable consumption. It is hard to imagine that prevailing power arrangements in some MENA states can be sustained without some accommodation of these interests. This holds special relevance in North Africa, where a distinct economic divide exists between the coastal and 
interior regions. Historically, development models in the region have displayed a clear coastal bias, leaving populations in the periphery economically marginalized ${ }^{18}$. In this milieu, incomes from smuggling can substitute for the state's prolonged social and economic neglect.

Border economies can simultaneously reduce the state's welfare burden and "act as a safety valve that defuses social violence, slows down the rural exodus, reduces unemployment, and offers alternative sources of income to people living in rebellious regions that are deprived of almost any public investment" (International Crisis Group 2013, 8). Informal cross-border trade is often the largest employer in regions where economic activity is overwhelmingly dominated by young workers with primary or secondary education and residents with incomes below poverty lines. ${ }^{19}$ Tunisia is a classic example. While formal state investment was already skewed towards coastal centres in years following independence, this intensified under Ben Ali as two-thirds of public investment went towards the coast (Meddeb 2017). Smuggling networks that developed alongside these imbalances were not just tolerated by the state, but as Gallien (2019) describes, also closely regulated. As these structures became increasingly entrenched, the state's engagement with these networks became a balancing act of control and toleration, since "the toleration of some smuggling is framed as an informal subsidy to the borderlands" (20).

The notion of an 'authoritarian bargain' is frequently invoked in the political economy literature to describe how MENA regimes distribute rents to their populations to buy political acquiescence (Malik 2012, Assaad 2014, Cammett et al. 2015). However, the strategic role of smuggling economies in the region's borderlands complicate this discussion in multiple ways. It highlights that these bargains are neither homogeneous nor uniform but, in fact, spatially uneven. Borderlands commonly experienced both different forms of rents than the political centre and different forms of rule. This is partly attributable to the states' frequent dependence on local elites and tribes as well as hybrid governance arrangements for administering border regions. These different forms of formal and informal bargains do not stand in conflict with each other but co-exist and interact across territory. It is also worth noting that these bargains are not uniform across borderlands, both within and 
across countries. This variation is rooted in historical developments of borderlands, the role of local elites, and the type of trading activity. For example, the economic and political autonomy of informal traders from Siwa on Egypt's western border vis-à-vis traders on its eastern border is shaped by heterogeneous political pressures associated with Egypt's neighbouring countries, such as Libya and Israel. It is also influenced by the types of goods traded and the historical role of border communities in mediating the relationship between the state and borderland regions. ${ }^{20}$ Integrating their spatiality and heterogeneity into wider discussions of authoritarian bargains not only helps to explain the mechanisms of authoritarian resilience in the MENA region but also illustrates why official attempts to formalise or eliminate this trade through administrative, regulatory and trade reforms are unlikely to succeed without any change in the underlying political settlement that is based on a correspondence between the distribution of resources with the underlying distribution of power. ${ }^{21}$

\subsection{Political economy of disorder}

Rents from informal cross-border trade are not only important in explaining how political order is sustained in times of peace, but can also reveal crucial information about the political economy of disorder. This holds special relevance in the Middle East, one of the most conflict-prone regions of the world where both coercive politics and resistance in the periphery are strongly influenced by rents generated through cross-border informality. Smuggling rents feature prominently in regional war economies that, in turn, connect with several important political economy questions: To what extent does conflict represent an institutional rupture? Are there strong institutional continuities between pre- and post-war institutional orders - and if so, why? What is the role of historical legacy in explaining the dynamics of conflict? Do factors that originally drive conflict often the same that perpetuate it? What determines the nature of post-conflict institutional order? And, what, if any, is the relevance of war economies for understanding the institutional foundations of corruption?

Before elaborating why and how cross-border informality is central for understanding these core political economy concerns, we begin by highlighting the role of borders in war economies. Even a cursory reading of 
the scattered academic literature on past and ongoing Middle Eastern conflicts underscores how resources from smuggling networks have fed the region's civil wars from Lebanon (1975-1990) to Algeria (1991-2002) and Iraq (1980-88 and post-2003). Beneath the multi-faceted sectarian strife of the Lebanese civil war lay a struggle for the control of ports, which was essential for smuggling of contraband (arms and narcotics) and raising cash for militant wings. While the Lebanese civil war was fed through a variety of rent streams generated through control of land and emigration, among others, the trade of licit and illicit goods shaped the dynamics of conflict in crucial ways (see, for example, Picard 2005). Along the same lines, Joffe's (2002) analysis on Algeria's civil war underscores how "violence itself was in part an outcome of politicized structure of the economy", and was used to resolve distributive claims in the face of eroding state authority $(2002,48)$. The interdependence of militias and smuggling similarly manifested in post-occupation Iraq where, according to Parker and Moore (2007), militant groups "carved out or co-opted their own areas of economic control and regulation" after the dissolution of Coalition Provisional Authority (CPA).

Ongoing civil wars in the Middle East reinforce this deep connection between cross-border informality and violence. Conflict dynamics can vary across different contexts ranging from Syria Iraq, Libya, and Yemen. However, in each case, the control of smuggling routes, the trafficking of migrants, crude oil, consumer products or essential consumables has become a crucial aspect of war economies. It helps to finance militias and incentivises key actors to maintain the status quo (Heydemann 2018). ${ }^{22}$ Two key rent streams fuelling the region's civil strife emanate from currency and fuel trade. In both Libya and Yemen, a significant difference exists between the official and black market exchange rate for dollars. This provides a key source of rent for warring factions. The "black market premium" is especially pronounced in Libya (see Figure 6). By proliferating opportunities for regional arbitrage, hugely depressed fuel prices in Libya are now a dominant source of rents for competing groups (see Figure 7). In Yemen, the Houthis and the UAE-backed militia groups control the import, distribution and sale of fuel in their respective areas of influence (Sana Center for Strategic Studies 2018). 
[Figures 6 and 7 here]

While smuggling incomes can undoubtedly sustain militant networks, the link between smuggling and militancy can be easily overstated. The nexus between radicalisation, violence and smuggling in borderlands is highly complex and defies simplistic causal characterisations. As Ahmad (2017) demonstrates, interactions between armed groups and informal economic enterprises may often be fuelled to the latter's need for affordable protection, rather than a common interest in destabilisation of the state.

Wartime institutional equilibria in the Middle East are shaped in crucial ways by pre-war institutional orders where both regimes and rebels continue to depend on prior institutions and norms. Rather than a complete breakdown of pre-conflict equilibrium, the same institutions are "re-deployed to serve war-time requirements" (Heydemann 2018, 50). War economies, partially fuelled by cross-border informality, provide a particularly important illustration of such institutional persistence and path dependence. Plentiful examples from the Middle East's past and contemporary conflict zones affirm this general insight. Post-invasion Iraq provides a dramatic illustration of the importance of historical legacy in understanding the growth of its war economy. In terms of historical legacy, three pre-occupation factors are especially important: the Iran-Iraq war (1980-88), the period of economic opening (infitah) after the war with Iran ended, and the UN sanctions. All three developments created a regulatory vacuum and resulted in a weakening of state capacity. With runaway inflation, persistent food shortages and public sector layoffs, pre-occupation Iraq was exposed to significant institutional and economic upheaval, thereby creating propitious conditions for the growth of informality, especially smuggling. As Parker and Moore convincingly argue: “As statist agency receded, it was replaced by conditions of multiple jurisdiction and sovereignty: localized social structures, transnational trade networks and a globalized sanctions regime came together to create new economic opportunities and impose new constraints" $(2007,7)$. 
These informal trade networks survived — and in many ways became more specialized—in the post-2003 period. After the US invasion, the control over supply chains of essential commodities became more diffused and internationalized. But these inter-dependent economic relations already existed prior to 2003 . The US invasion simply changed the spatial significance of regional trade routes, increasing the importance of the Highway 8 that linked Baghdad with Basra and Kuwait and decreasing the significance of the westward link between Falluja and Jordan through Highway 10 (Parker and Moore 2007). Echoes of this can also be found in Algeria where the war economy that fed the civil war in the 1990s was shaped by the weakening of state authority in the pre-conflict period. As the state temporarily reduced its economic footprint, it was not replaced by a formal private sector but by a thriving informal economy that fostered alternative "political and social networks" around which "collective life" came to be organized (Joffe 2007, 43). Joffe further observes: "as unemployment grew, parallel trade based on smuggled goods and on access to state supplies increased, creating the trabando phenomenon, whereby unemployed youth were drawn into the parallel economy's distribution circuit" (p 42).

The Lebanese civil war created multiple competing entrepreneurs of war who relied on smuggling of licit and illicit goods, rents from land speculation and emigration (Picard 2005). Resources that sustained the Lebanese civil war were generated through activities, such as drug trafficking, and tolerated by the Lebanese state in pre-war years with the blessing of top political elites. The civil war simply changed the scale and scope of these networks and proliferated new actors of accumulation. As Picard aptly notes: "Militia entrepreneurs did not invent a new Lebanese economy, even less a "war economy". Rather, they took advantage of the structure of opportunities offered by the Lebanese environment and distribution of power" $(2005,48)$. In fact, the broader political economy patterns that came to define Lebanon during and after the civil war were strongly conditioned by history, including Ottoman legacy.

Heydemann's analysis of ongoing civil wars in Syria, Yemen and Libya underscores similar institutional continuities. These civil wars have witnessed the reproduction of the authoritarian political economy of the 
pre-war era. In Libya, tribal networks tied to Gaddafi were "implicated in the rise of human trafficking that Libya experienced in the 2000s" (Heydemann 2018). With Gaddafi's ouster, the control over this lucrative trade became more decentralized and turned into an important arena of competition for different militia groups. Similarly, the smuggling rackets that were active in Yemen in the pre-civil war years persisted and evolved during the period. The pattern of state capture that defined Yemeni political economy in times of peace offers an important backdrop within which militia groups have come to dominate state institutions, the country's revenue streams, and networks of patronage formed during conflict (Sana Centre for Strategic Studies 2018).

In the face of this strong evidence of institutional persistence, it is worth asking what has actually persisted. The persistent features are: informal networks of privilege emphasized by Heydemann (2018); the predatory nature of economic interventions, the use of cronies and informal operators in markets, dependence on coercion to extract rents, dispersal of economic authority to non-state agents and the "porous" boundaries between formal and informal sectors. Conflict has only exacerbated these pre-war institutional anomalies by fracturing political authority and fragmenting economic activity. It has thus led to a greater intensification and specialization of the war economy, but the underlying institutional incentives and norms remain intact as both regimes and rebels in these countries are playing by the same rulebook. Rather than imposing a strict and artificial separability between institutional orders that exist in times of peace and war, it is important to develop a deep and temporally rich political economy view of cross-border informality. This can afford a new window into questions of perennial importance in the literature, involving the role of institutional persistence, path dependence, and the need to explain continuity in the midst of change.

A better understanding of the relationship between war economies and cross-border informality can also substantially enrich the political economy analysis of conflict. While the drivers of conflict are multi-faceted in nature, civil wars assume an economic logic of their own that is sometimes distinct from the original drivers of conflict. Scattered analyses of war economies across the Middle East suggest that factors that sustain or prolong a conflict could be different from those explaining its onset. Lebanon offers an illuminating case in 
this regard where the ideological and sectarian differences that originally fed the conflict were foreshadowed by pure war profiteering and greed by militia groups. As Picard (2005) shows, the logic of war economy both intensified and prolonged the conflict, especially after the militia groups' dependence on support from neighbouring countries declined and their hold over local supply chains intensified.

Analysis of cross-border informality can also sharpen our understanding of the political economy impact of conflict. While civil wars constitute a dramatic disruption, they do not necessarily suspend market and governance relations. The exceptional circumstances of conflict support the unexceptional politics of survival where actors on all sides of the divide are compelled to operate in a mutually inter-dependent space, thereby creating a complex domain of both cooperation and conflict. In Syria, the need to access essential commodities, such as wheat, oil, power, and water supplies has incentivized opposing parties in the conflict to reach “negotiated agreements" (Heydemann 2018). In Yemen, fuel import permits that are granted by Saudi Arabia with the express permission of President Hadi have generated massive rent streams where different warring factions can dip in through their brokers (Sana Centre for Strategic Studies 2018). Such sharing of spoils was also a hallmark of the Lebanese civil war where cooperative exchange crisscrossed sectarian and ethnic lines. Militias that fought against each other on streets were actually able to negotiate their respective domains of economic influence with each other (Picard 2005).

While clearly driven by the imperative of survival and war profiteering, such cooperative interactions are a ubiquitous feature of conflict settings and carry profound implications for post-war political economy. By enhancing the sheer scale of informality and creating a more decentralized control over supply chains, conflict supports new actors who are invested in maintaining the status quo. In the Syrian context, Cammack et al. (2017, p. 23) note that around " 17 percent of Syria's active population is involved in the conflict-related economy, creating a new stratum that has grown wealthy from the war". Iraq's experience under US sanctions - and after the US invasion - also points to the emergence of "new configurations of regulatory power" that replaced old structures and were not entirely "contained within Iraq's borders" (Parker and Moore 
2007). These new agents of accumulation, brokers, and business intermediaries became a new reality that any post-conflict order had to deal with. In fact, no post-conflict political settlement can afford to ignore the institutional shifts brought by war economies. The post-civil war Lebanon shows how territorialisation of the economy that resulted from militia groups carving out their respective economic domains was regularized after the Taif agreement in 1989 that ended the civil war (Picard 2005, Leenders 2012). In its wake, the economy was partitioned on sectarian lines. An example is the deregulation of oil trade that converted the state monopoly into an oligopoly controlled by six private companies each associated with a militia group. As Picard (2005, 34) argues: "What post-war official measures induced was not a break from the war economy but its modernization and routinization".

A war economy fuelled by smuggling also holds immense relevance for the institutional and policy discourses on corruption. It is widely recognized that corruption has deep political foundations (Rothstein 2011). While there is an expanding literature on the political analysis of corruption, clientelism, and state capture in times of peace, conflict settings can critically refine our understanding of corruption. This is because economic and political shifts brought by conflict can bring enduring changes in the institutional landscape for corruption. From Iraq and Yemen to Libya and Lebanon, the shadow networks that prospered during conflict have tried to capture the state's authority and resources. The corruption that takes root in such contexts is a by-product of the fragmentation of state authority and informalization of economies during conflict. It is an equilibrium outcome associated with a complex and fragile political settlement that rests, among other factors, on rentsharing arrangements between competing groups. As Leenders (2012) argues in the Lebanese context, corruption can be framed as the "spoil of truce" - a necessary cost to be paid for peace. Thus, a political economy analysis of cross-border informality can hugely enrich our understanding of the causes, consequences and control of corruption. 


\subsection{Laboratory for institutional analysis}

Borderlands provide useful laboratories to explore the origin of informal institutions, their interaction with formal institutional structures, the mechanisms through which they impact, and the actors and interests behind them. Informal institutions, defined by Helmke and Levitsky $(2004,37)$ as "socially shared rules, usually unwritten, that are created, communicated, and enforced outside of officially sanctioned channels", have recently taken centre stage in political economy discussions around governance, state formation, and 'development with the grain'. A key question regarding informal institutions is how they are "modified, adapted, or even reinvented over time". Going beyond simplistic binary distinctions between formal and informal, and between personalized and impersonal exchange, border economies can both challenge and enrich modern political economy analysis. In this regard, we highlight four key areas of research: the role of informal institutions in personalised exchange, their features, territoriality, and relevance for International Political Economy (IPE).

First, the study of informal institutions in borderlands can provide critical insights into the mechanics of personalized exchange. Operating against or outside the law, and in areas of hybrid governance, informal trade relies on informal norms, markers of symbolic power and socially embedded arrangements to limit uncertainty and build trust. The regulatory function that tribes and religious institution can play here is crucial for unpacking common conceptions of personalised exchange. MENA's borderlands-frequently located in areas of limited statehood, and limited formal economic integration - provide ideally placed sites for the study of informal institutions. For example, in her study of smuggling networks and connectivity across the Sahara, Scheele (2012) points to the role that religious orders and social capital have played in connecting trade, commerce, and vast territories.

Second, while informal institutions are commonly described as being primarily relevant to personalized exchange, cross-border trade in the MENA region has also demonstrated features more commonly attributed 
to impersonal exchange: anonymity, one-shot interactions, or third-party enforcement. This provides an excellent empirical context to challenge common characterisations of informal institutions as self-enforcing, unwritten, small-scale or personalised. Smuggling at one of the main border posts between Tunisia and Libya, for example, has, for decades, been structured through informal institutionalised agreements. Despite the illegal nature of the business, these agreements operate impersonally and establish rules for smugglers irrespective of their connections or origin (Gallien 2019). These agreements specified not only the types of goods that could be smuggled through the border crossing - notably frequently barring the entrance of goods that were traded by politically connected crony networks — but also the levels of bribes that needed to be paid, and how these would be divided between different actors along the border. While typically unwritten, as mainstream political economy literature widely assumes of informal institutions, a written version of such an agreement briefly existed for the first few months of 2014. It was signed not only by local civil society actors and smugglers but even a member of parliament (until a novel re-negotiation of the agreement was once again unwritten). Similar arrangements can be observed along Morocco's borders with the Spanish enclaves of Ceuta and Melilla, or until 2013, its border with Algeria, where they regulate — once again, broadly impersonallynot only the types of goods that can be smuggled, but also their quantity and prices. ${ }^{23}$

Borderlands in the MENA region not only provide an ideal setting for a re-examination of commonly held assumptions around informal institutional structures; they can also help to question the boundaries between formal and informal institutions themselves. In a range of borderlands across the region, informal and formal actors observe multiple levels of regulation. For example, a formally registered enterprise might still pay allegiance to local religious or tribal groups while informal traders can be required to submit to some form of taxation. Informal trade thus at times operates in a hybrid institutional milieu that is characterised by Legal Pluralism. In this context, informal institutions defy a simple binary distinction between personal and impersonal exchange, which has remained fundamental to mainstream political economy. 
Third, the study of MENA's borderlands highlights the spatiality of informal institutions. While much of the literature conceptualises informal institutions as small and localised, their role in connecting actors and economic streams in the arid borderlands of the MENA region - the Sahara and the deserts of the Arabian Peninsula, for example — highlight their ability to connect a vast territory. Scheele (2012) highlights how tribal networks, marital ties, and religious orders have served to connect and integrate the Sahara as an economic space, with formal and informal trade networks spanning thousands of miles. Here, crucial dimensions of economic and symbolic power are co-created across borderlands. Sufi sheiks of the Senussi order strategically placed themselves along major trade routes in Libya and Sudan, establishing important agricultural settlements and trade centres. Their legitimacy was largely drawn from their ability to broker religious, social and trading relations and their resistance to imperial powers (Ahmida 1994). Informal institutions lie at the heart of these spatial and symbolic connectivities that previous literature had commonly conceptualised as un-connected. Recent studies of the borderland regions of Egypt and Libya echo the same message (Hüesken 2018, Ellis 2018). Connectivity and regulation along the Egypt-Libya corridor are also provided through informal institutions typically built on tribal identities, such as the fraternity of Awlad Ali tribe, but at the same time stands in constant interaction and engagement with state power on both sides of the border.

Politics is key to understanding how border economies function: profits from smuggling can be ploughed back into local politics through vote purchases and other forms of clientelistic exchange. In this context, border economies are crucial for understanding the local competition for political dominance and appropriation of state resources. MENA's borderlands do not just provide a beneficial context for the study of informal institutions themselves, but also for the study of their relationship with territoriality, their role in the expansion and limitation of both empire and the nation-state, and the institutions of globalisation. Importantly, they pose a direct challenge to the common conceptualisation of informal institutions as local and spatially limited.

Fourth, and following naturally from the above point, MENA borderlands provide an excellent meeting ground for the study of informal institutions, informal trade and IPE. As Andreas (2004) has noted, traditional divides 
between IPE, security studies and international relations has long limited the engagement of IPE with informal and illegal trade. In this regard, informal institutions are crucial to organising economic relations in borderlands. They represent critical nodes in international trade relationships and help regulate the flow of goods and finances. They can thus provide critical inputs into mainstream debates in IPE.

As Naylor (2005), Naim (2006) or Andreas (2004) have highlighted, processes of globalisation are closely entwined with informal cross-border trade. Technology that has facilitated formal transnational commerce has benefited informal trade. But the relationship can also run in the opposite direction. For example, Hawala networks, a traditional method of informal banking that is common in MENA borderlands, have increasingly been copied by formal financial providers such as Transferwise ${ }^{24}$. In a recent paper, Blanton et al (2018) have suggested that economic openness will decrease the size of 'shadow economies', while the engagement with IMF programs may increase it. Meagher (2003) found that economic restructuring has gone hand in hand with the expansion and globalisation of informal economic networks.

These considerations add important layers to classic IPE discussions. The debate around the effects of globalisation on state power cannot be separated from the effects that globalisation has had on informal economies, but also the degree to which states are still regulating and structuring informal economies through their engagement with informal institutions. Both as constituencies and as potentially subversive actors, border communities are important to consider in estimating the social and economic effects of embargoes and sanctions (Andreas 2005). In addition, any analysis of the way formal institutional architectures of global trade have affected developing countries will remain incomplete without considering informal trade structures and their institutional regulation.

Admittedly, borderlands are not the only spaces in which informal institutions can be studied. Informality is pervasive across the region—-from rural markets to urban street vendors. However, several core features of borderlands situate them as distinct laboratories for studying the role of informal institutions. Informal 
institutions arguably play a comparatively more important role in mediating traders' uncertainty in the periphery, where informal trade networks often dominate local economies and where enforcement capacities of states are particularly limited or mediated. In such contexts, border economies span multiple jurisdictionsengaging with different state authorities and at the same time often drawing on relationships with tribal groups, religious brotherhoods or other networks in order to mediate between heterogeneous and changing regulatory structures. As argued before, borderlands also highlight the role of informal institutions in connecting disparate regions and connecting the local with the global. They are thus particularly relevant to contemporary discussions in modern IPE around the changing power of states in the context of globalisation, and the role of technology in shaping global trade structures. It is also worth noting that the negotiation of informal and hybrid institutions in a borderland setting have a different dynamic vis-à-vis urban centres through the heightened engagement with symbols of state sovereignty, such as the border itself, or the presence of the military as a monopolist on the use of violence. As recent anthropological studies on Africa's borderlands have highlighted (Raeymaekers 2014; Titeca and Herdt 2010), border regions provide a particularly fruitful setting for the study of informal institutions in the context of fragmented state sovereignty and hybrid governance.

\subsection{Regional inter-dependence}

Underneath different strands of analysis developed in previous sections lies a cross-cutting theme: the fundamental interdependence between domestic and external political economy domains. Border economies provide a perfect entry point for analysing the complex ways in which domestic political economy of Middle Eastern states is inter-woven through "complex entanglements with regional and global networks of authority and exchange" (Parker and Moore, 2007, 15). As discussed earlier, Iraq's Baathist regime was able to bypass international sanctions by deftly managing its cross-border informal trading relations with Jordan. It is useful to highlight, however, that during the same period, the Jordanian regime was also able to privilege its cronies and rural East banker tribes in these informal trading relations and buy greater political security in a period of financial turbulence. The larger point emphasized by this example is that the durability of both Iraq's Baathist 
and Jordan's Hashemite regime was co-constituted during the 1980s and 1990s, and that border economies played a crucial role in this. Consequently, their study can push political economy scholarship on the Middle East towards systematically expanding its focus beyond national boundaries.

Fuel smuggling particularly underscores the fluid boundaries between national and international domains. As Figure 4 illustrates, there are sharp variations in fuel prices across the region, driven by differences in resource endowments and subsidy regimes, which create substantial arbitrage opportunities in a region where about half of the global energy subsidies are distributed every year. This regional dimension in the distribution of fuel subsidies is critical for any meaningful subsidy reform, since such reform can seriously affect the livelihood of border communities and eat into rent streams of influential local actors. As a result, subsidy reforms or changes in the regulation of fuel trade in one country can endanger the stability in a neighbouring political jurisdiction. For example, in recent years Algeria's tighter enforcement on its borders has had severe economic impacts on Morocco's northern borderlands, which were heavily dependent on smuggled fuel. Similarly, the reform of fuel subsidies in Algeria or Libya, frequently discussed in recent years, would directly affect Tunisia's southern borderlands. The World Bank and IMF, who have worked and published extensively on these issues in recent years, have so far largely ignored the importance of regional linkages and complementarities in relation to subsidies. Any large-scale reform of fuel and food subsidies in the region will have to consider borderland communities as a critical constituency.

The inter-connectedness of internal and external domains is further highlighted in the wake of geopolitical shocks. Disruption of formal trade channels due to wars, sanctions and border closures can give a major boost to smuggling. International sanctions on Libya, Iraq, Iran and Syria, have provided plentiful opportunities for covert economic exchange organized with the complicity of local patrons and involvement of regional and transnational networks of self-interested agents. When Libya faced international sanctions in the 1990s, illegal trade networks operating in southern Tunisia served its markets (Meddeb 2012). Further east, sanctions against Iran created a busy illegal trade route across the Gulf of Oman, through which speed boats have long supplied 
Iranian bazaars. Border closures triggered by regional conflicts and geopolitical instability also support the growth of informal trade. The development of informal channels to supply Gaza from Egypt is a muchdiscussed example (Almog 2004; Pelham 2012). When wars shut down formal trade channels, warring groups with control over natural resources tend to use informal networks to sell captured resources. The smuggling of gasoline organised by ISIS provides a pertinent example.

Borderlands can also offer a window into the negative externalities of foreign interventions, whether through direct military action or proxy groups. Interventions in Iraq (post-2003), Libya, Syria, and Yemen have created environments where internal and external dynamics are blurred, not just temporarily, but as fundamental constitutive elements of the system. They have resulted in a dual fragmentation of states and markets. Contemporary Libya is in a state of fragmentation between multiple governments, authorities, administrative, and security structures. The regulatory vacuum generated by these multiple overlapping and competing jurisdictions has contributed to the proliferation of smuggling and created groups who have a vested interest in state capture thereby institutionalizing corruption and clientelism (Eaton 2018). At the same time, the impact of these networks on neighbouring countries has further pulled regional actors into the Libyan conflict. The Libyan political economy is thus no longer governed today by domestic dynamics alone but is shaped by a complex array of foreign influences that hold the key to solving the country's multiple collective action problems.

This offers an important intersection point for border economies and important contemporary debates in IPE, including the role of state-building and reconstruction in post-conflict settings (Paris and Sisk 2009; Hartzell and Hoddie 2007; Fearon and Laitin 2003). In conflict settings where uncertainty is rife, time horizons are short, and investments are long-term in nature, it is difficult to secure credible commitments from different stakeholders involved in reconstruction, since their promises today may run counter to their incentives to fulfil them in future. Such temporal disconnect between incentives and choices is a classic political economy challenge, and can become a major obstacle to reconstruction since the fear of security of investments fosters 
underinvestment of physical and human capital (Besley and Persson 2010; Flores and Nooruddin 2011; Coyne and Boettke 2009).

By obscuring the distinction between internal and external domains, cross-border informality in war-torn countries intensifies these institutional challenges. As argued earlier, many new contenders for power that emerge in the wake of conflict derive their rents from participation in and control of smuggling networks. Solving the commitment problem for post-conflict reconstruction requires paying close attention to the interests and incentives of these actors, not just in one but multiple jurisdictions since they are inserted in transnational exchange. The multiplicity of local, regional, and international actors involved in these conflict settings means that more sophisticated mechanisms for coordination and commitment need to be devised. For example, citizens will need to judge the credibility and commitment of both indigenous actors (e.g. various ethnic and sectarian groups) and external actors involved in cross-border informality. The strong regional complementarities to addressing the reconstruction challenge effectively implies that solving a commitment problem in one country or sub-region can be inter-linked with addressing a similar challenge in a neighboring jurisdiction.

In conclusion, informal trading networks in borderlands make it difficult to usefully study political economy in terms of the nation-state framework. This has important bearing for Middle Eastern Studies, which has, so far, been resolutely methodically nationalist. The classic text in the field by Richards and Waterbury (and the recent update by Cammett et al, 2015) has predominantly concerned itself with domestic dynamics, dealing tangentially with external dynamics mainly in the context of war and conflict. Beyond a cursory recognition, the role of transnational factors and broader international trends in political economy still needs to be systematically worked out. Concluding their analysis on Iraq's war economy, Parker and Moore $(2007,15)$ echo the same concern: "By designating the Iraqi state, the Iraqi economy and society as discrete objects of transition, mainstream analysis obscured the extent to which state, economy, and society were in fact linked to broader complexes of production and exchange that extended far beyond Iraq's borders" (p. 15). A more 
rigorous political economy understanding of the Middle East's border economies can also productively contribute to larger conversations about hierarchy in international relations and the growing entanglements between domestic and external domains (Lake 2009, 2013, 2016).

\section{Conclusion}

Borderland regions of the Middle East exist not just on the margins of physical geography but also remain peripheral to dominant narratives on its political economy. In this article, we have argued that cross-border informality is not simply a residual category that is to be analyzed only through a security lens, and treated as a field of crime and punishment. Rather, it can provide crucial signposts to addressing some of the central questions of MENA political economy. Borderlands offer a fertile ground for studying how state authority is constituted and contested in peripheral regions, how social contracts accommodate or exclude tribes and trading communities on the margins, and how political settlements are shaped by diverse constituencies commonly ignored in mainstream analysis.

In highlighting their relevance, we have shown how studying borderlands through a political economy lens can generate constructive inputs for larger debates in MENA scholarship revolving around regime durability and state formation, and the centrality to the political economy of disorder. We have also pointed to their utility as a laboratory for the analysis of informal institutions, and the role that border economies can play in pushing political economy scholarship in the Middle East beyond its methodological nationalism and engage it with central discussions in the IPE literature.

In light of these arguments, it is worth asking why so little research has gone into in this field. Key challenges include security and ethical difficulties in conducting field research; methodological challenges associated with studying informal economic processes, scarcity of interdisciplinary engagement, and the systematic neglect of cross-border informality in the dominant academic discourse on MENA political economy. In order 
to move forward, the study of border economies warrants a more diverse and multi-disciplinary use of methodology that goes beyond mirror statistics and small-scale surveys. Developing more creative methods of data collection, such as the Open Pack Survey directed by Philip Morris International or the satellite data analyzed by Bensassi et al. (2015), can be productive avenues.

Besides, a more systematic engagement of MENA political economy scholarship with in-depth qualitative fieldwork on the issue is important. As discussed in this article, the types of goods traded, nature of actors and communities involved, differences in regulatory structures in neighboring countries, and physical geography shape significant variety in smuggling structures and networks. Social scientists can harness these different sources of variation through paired comparisons between networks, types of goods or borderlands. In addition, recent policy changes in border control, disruptions to trade routes, and changes in tariff and sanction regimes offer opportunities to study border economies through examining shocks and natural experiments. Such intellectual endeavors could benefit from rich discourses on informal trade that already exist in human geography, urban studies, economic anthropology, and sociology. ${ }^{25}$ By doing so, these studies can also inform and enrich the larger literature on political economy beyond the Middle East.

Beyond the academic realm, a new understanding of cross-border informality is essential for policymakers trying to grapple with some of the Middle East's most intractable development challenges. Reforming subsidy programs, tariff regimes, or securitizing borders in the Middle East without a detailed understanding of the region's informal trade structures would be a grave mistake. Existing policy discourse typically views smuggling from a security lens and suggests administrative measures, such as better policing and border enforcement, to deal with it. However, a neglect of the social and political aspects of informal cross-border trade will not only produce unexpected side effects of policies but also undermine their very purpose. Stricter enforcement regimes have not been able to halt the illegal flow of goods. There is no more striking evidence of this fact than the large presence of informal trade in the region now, and its growth in recent years. In short, this paper has highlighted the need for an entirely different imagination of border regions that goes beyond the 
simplistic binary between legal and illegal and considers borderlands as complex political and economic spaces. In order for political economy scholarship to contribute to this perspective, it needs to re-engage with borderlands, and move the region's geographic periphery closer to the center of its scholarship. 


\section{References}

Ahmad, Aisha. 2017. Jihad \& Co.: Black Markets and Islamist Power. Oxford, New York: Oxford University Press.

Ahmida, Ali Abdullatif. 1994. The Making of Modern Libya: State Formation, Colonization, and Resistance, 1830-1932. SUNY Press.

Almog, Doron. 2004. “Tunnel-Vision in Gaza.” Middle East Quarterly, June. https://dev.meforum.org/630/tunnel-vision-in-gaza.

Anderson, Lisa. 1987. The State and Social Transformation in Tunisia and Libya, 1830-1980. Princeton, NJ: Princeton University Press.

Andreas, Peter. 2004. "Illicit International Political Economy: The Clandestine Side of Globalization." Review of International Political Economy 11 (3): 641-52. https://doi.org/10.1080/0969229042000252936. . 2005. "Criminalizing Consequences of Sanctions: Embargo Busting and Its Legacy." International Studies Quarterly 49 (2): 335-60. https://doi.org/10.1111/j.00208833.2005.00347.x.

Assaad, Ragui. 1993. "Formal and Informal Institutions in the Labor Market, with Applications to the Construction Sector in Egypt." World Development 21 (6): 925-39. https://doi.org/10.1016/0305-750X(93)90052-B. . 2014. "Making Sense of Arab Labor Markets: The Enduring Legacy of Dualism." IZA Journal of Labor \& Development 3 (April): 6. https://doi.org/10.1186/2193-9020-3-6.

Ayadi et al. 2013. "Estimating Informal Trade across Tunisia's Land Borders." World Bank Report WPS6731. Policy Research Working Paper. World Bank.

http://econ.worldbank.org/external/default/main?pagePK=64165259\&theSitePK=469382\&p $\mathrm{iPK}=64165421 \&$ menuPK=64166093\&entityID=000158349_20131223113808.

Ayubi, Nazih N. 1996. Over-Stating the Arab State: Politics and Society in the Middle East. New edition edition. London New York: I.B.Tauris.

Bayat, Asef. 1997. "Un-Civil Society: The Politics of the 'Informal People.'" Third World Quarterly 18 (1): 53-72. https://doi.org/10.1080/01436599715055.

Bellin, Eva. 2004. "The Robustness of Authoritarianism in the Middle East: Exceptionalism in Comparative Perspective." Comparative Politics 36 (2): 139-57. https://doi.org/10.2307/4150140.

Bensassi, Sami, Anne Brockmeyer, Gael J. R. F. Raballand, and Matthieu Pellerin. 2015. "Commerce Algérie - Mali : la normalité de l'informalité." 101137. The World Bank. http://documents.worldbank.org/curated/en/202591468195569460/CommerceAlg\%C3\%A9rie-Mali-la-normalit\%C3\%A9-de-1-informalit\%C3\%A9.

Besley, Timothy, and Torsten Persson. 2010. "State Capacity, Conflict, and Development." Econometrica 78 (1): 1-34. https://doi.org/10.3982/ECTA8073.

Blanton, Robert G., Bryan Early, and Dursun Peksen. 2018. "Out of the Shadows or into the Dark? Economic Openness, IMF Programs, and the Growth of Shadow Economies." The Review of International Organizations 13 (2): 309-33. https://doi.org/10.1007/s11558-018-9298-3.

Boone, Catherine. 1994. "Trade, Taxes, and Tribute: Market Liberalizations and the New Importers in West Africa." World Development 22 (3): 453-67.

Boughzala, Mongi, and Mohamed Hamdi. 2014. Promoting Inclusive Growth in Arab Countries. Global Economy and Development. Washington, DC: Brookings.

Brandell, Inga. 2006. State Frontiers - Borders and Boundaries in the Middle East. London: I.B. Tauris. 
Cammack, Perry, Michele Dunne, Amr Hamzwy, Marc Lynch, Marwan Muasher, Yezid Sayigh, and Maha Yahya. 2017. Arab Fractures: Citizens, States, and Social Contracts. Carnegie Endowment for International Peace.

Cassarino, Jean-Pierre. 2017. "Approaching Borders and Frontiers in North Africa." International Affairs 93 (4): 883-96. https://doi.org/10.1093/ia/iix124.

Coyne, Christopher J., and Peter J. Boettke. 2009. "The Problem of Credible Commitment in Reconstruction*." Journal of Institutional Economics 5 (1): 1-23. https://doi.org/10.1017/S1744137408001197.

Dauvergne, Catherine. 2004. "Sovereignty, Migration and the Rule of Law in Global Times." The Modern Law Review 67 (4): 588-615.

Diamond, Larry. 2015. In Search of Democracy. 1 edition. Milton Park, Abingdon, Oxon; New York, NY: Routledge.

Eaton, Tim. 2018. Libya's War Economy: Predation, Profiteering and State Weakness. London, UK: Chatham House.

https:/www.chathamhouse.org/sites/files/chathamhouse/publications/research/2018-04-12libyas-war-economy-eaton-final.pdf.

Eibl, Ferdinand. 2019. Social Dictatorships: The Political Economy of the Welfare State in the Middle East and North Africa. Oxford: Oxford University Press.

Eibl, Ferdinand, and Adeel Malik. 2016. "The Politics of Partial Liberalization: Cronyism and NonTariff Protection in Mubarak's Egypt.” 2016-27. CSAE Working Paper Series. Centre for the Study of African Economies, University of Oxford. https://ideas.repec.org/p/csa/wpaper/2016-27.html.

Ellis, Matthew H. 2018. Desert Borderland: The Making of Modern Egypt and Libya. 1 edition. Stanford, California: Stanford University Press.

Elyachar, Julia. 2005. Markets of Dispossession: NGOs, Economic Development, and the State in Cairo. 49320th edition. Durham: Duke University Press Books.

Farzanegan, Mohammed Reza. 2007. "Illegal Trade in the Iranian Economy: A MIMIC Approach." In . Cairo.

Fearon, James D., and David D. Laitin. 2003. "Ethnicity, Insurgency, and Civil War." American Political Science Review 97 (1): 75-90. https://doi.org/10.1017/S0003055403000534.

Flores, Thomas Edward, and Irfan Nooruddin. 2011. "Credible Commitment in Post-Conflict Recovery." In Chapters. Edward Elgar Publishing. https://ideas.repec.org/h/elg/eechap/13385_23.html.

Freund, Caroline, Antonio Nucifora, and Bob Rijkers. 2014. "All in the Family: State Capture in Tunisia." WPS6810. The World Bank. http://documents.worldbank.org/curated/en/440461468173649062/All-in-the-family-statecapture-in-Tunisia.

Gallien, Max. 2018. Understanding Informal Economies in North Africa: From Law and Order to Social Justice. Friedrich Ebert Stiftung. http://library.fes.de/pdf-files/iez/14573.pdf. . 2019. "Informal Institutions and the Regulation of Smuggling in North Africa." Perspectives on Politics. https://www.cambridge.org/core/journals/perspectives-on-politics.

Haddad, Bassam S. A. 2012. Business Networks in Syria: The Political Economy of Authoritarian Resilience. 1 edition. Stanford, Calif: Stanford University Press.

Hanlon, Querine, and Matthew Herbert. 2015. "Border Security Challenges in the Grand Maghreb." United States Institute of Peace Press. 
Hartzell, Caroline A., and Matthew Hoddie. 2007. Crafting Peace: Power-Sharing Institutions and the Negotiated Settlement of Civil Wars. Penn State University Press.

https://www.jstor.org/stable/10.5325/j.ctt7v5x0.

Helmke, Gretchen, and Stephen Levitsky. 2004. "Informal Institutions and Comparative Politics: A Research Agenda." Perspectives on Politics 2 (4): 725-40.

Hertog, Steffen, Giacomo Luciani, and Mark Valeri, eds. 2015. Business Politics in the Middle East. 1 edition. London: Hurst.

Heydemann, Steven. 2004. Networks of Privilege in the Middle East: The Politics of Economic Reform Revisited. Palgrave Macmillan. https://www.palgrave.com/gp/book/9781403963529. . 2018. "Civil War, Economic Governance \& State Reconstruction in the Arab Middle East." Daedalus 147 (1): 48-63. https://doi.org/10.1162/DAED_a_00473.

Hibou, Beatrice. 2011. The Force of Obedience. 1 edition. Cambridge: Polity.

Hüsken, Thomas. 2018. Tribal Politics in the Borderland of Egypt and Libya. 1st ed. 2019. New York, NY: Palgrave Macmillan.

International Crisis Group. 2013. "Tunisia's Borders: Jihadism and Contraband." Middle East and North Africa Report 148. International Crisis Group.

http://www.crisisgroup.org/en/regions/middle-east-north-africa/north-africa/tunisia/148tunisia-s-borders-jihadism-and-contraband.aspx.

Joffé, George. 2002. "The Role of Violence Within the Algerian Economy." Journal of North African Studies 1 (7).

Khan, Mushtaq. 2010. "Political Settlements and the Governance of Growth-Enhancing Institutions." Draft Paper in Research Paper Series on "Growth-Enhancing Governance."

Lake, David A. 2009. Hierarchy in International Relations. Cornell Studies in Political Economy. Ithaca, NY: Cornell University Press. . 2013. "Legitimating Power: The Domestic Politics of U.S. International Hierarchy." International Security 38 (2): 74-111. https://doi.org/10.1162/ISEC a 00139. . 2016. The Statebuilder's Dilemma: On the Limits of Foreign Intervention. Ithaca, NY: Cornell University Press.

Laroussi, Kamel. 2013. “L'espace Frontalier Tuniso-Libyen Dans La Tourmente de La Mondialisation et Prospection Conceptuelle Des Nouvelles Formes d'urbanités et de Gouvernances Dans Les Nouvelles «régions Économiques».” Revue Des Régions Arides, no. 31.

Leenders, Reinoud. 2012. Spoils of Truce: Corruption and State-Building in Postwar Lebanon. Ithaca, NY: Cornell University Press.

Malik, Adeel. 2017. "Rethinking the Rentier Curse." International Development Policy $\mid$ Revue internationale de politique de développement 7 (7). https://doi.org/10.4000/poldev.2266.

McMurray, David A. 2001. In and out of Morocco: Smuggling and Migration in a Frontier Boomtown. Minneapolis: University of Minnesota Press. https://catalyst.library.jhu.edu/catalog/bib_4691182.

Meagher, Kate. 2003. "A Back Door to Globalisation?: Structural Adjustment, Globalisation \& Transborder Trade in West Africa." Review of African Political Economy 30 (95): 57-75. . 2014. "Smuggling Ideologies: From Criminalization to Hybrid Governance in African Clandestine Economies." African Affairs 113 (453): 497-517. . 2018. "Cannibalizing the Informal Economy: Frugal Innovation and Economic Inclusion in Africa." The European Journal of Development Research 30 (1): 17-33.

Meddeb, Hamza. 2012. "Courir ou mourir: course à el khobza et domination au quotidien dans la Tunisie de Ben Ali." Thèse de doctorat, Paris, France: Institut d'études politiques. 
2017. Peripheral Vision: How Europe Can Help Preserve Tunisia's Fragile Democracy. ECFR Policy Brief.

https://www.ecfr.eu/publications/summary/peripheral_vision_how_europe_can_preserve_tu nisias_democracy_7215.

Meier, Daniel. 2018. "Introduction to the Special Issue: Bordering the Middle East." Geopolitics 23 (3): 495-504. https://doi.org/10.1080/14650045.2018.1497375.

Migdal, Joel S. 2008. Boundaries and Belonging: States and Societies in the Struggle to Shape Identities and Local Practices. 1 edition. Cambridge: Cambridge University Press.

Milton-Edwards, Beverley. 2018. Contemporary Politics in the Middle East. 4th edition. (Cambridge, UK); Malden, MA: Polity Press.

Naim, Professor Moises. 2006. Illicit: How Smugglers, Traffickers, and Copycats Are Hijacking the Global Economy. New York: Anchor Books.

Naylor, R. T. 2005. Wages of Crime: Black Markets, Illegal Finance, and the Underworld Economy. Ithaca, NY: Cornell University Press.

North, Douglass C., John Joseph Wallis, and Barry R. Weingast. 2009. Violence and Social Orders: A Conceptual Framework for Interpreting Recorded Human History. Reprint edition. Cambridge University Press.

Paris, Roland, and Timothy D. Sisk, eds. 2009. The Dilemmas of Statebuilding: Confronting the Contradictions of Postwar Peace Operations. 1 edition. London ; New York: Routledge.

Parker, Christopher, and Peter Moore. 2007. "The War Economy of Iraq." Middle East Report, no. 243 (Summer).

Pelham, Nicolas. 2012. "Gaza's Tunnel Phenomenon: The Unintended Dynamics of Israel's Siege." Journal of Palestine Studies 41 (4): 6-31. https://doi.org/10.1525/jps.2012.XLI.4.6.

Picard, Elizabeth. 2005. "Trafficking, Rents, and Diaspora in the Lebanese War," September, 2767.

Raeymaekers, Timothy. 2012. "African Boundaries and the New Capitalist Frontier." In Companion to Border Studies, edited by Thomas M. Wilson and Hastings Donnan. Chichester, UK: John Wiley \& Sons, Ltd. 2014. Violent Capitalism and Hybrid Identity in the Eastern Congo: Power to the Margins. New York, NY: Cambridge University Press.

Richards, Alan, and John Waterbury. 2007. A Political Economy of the Middle East. 3 edition. Boulder, Colo: Westview Press.

Rogan, Eugene. 2009. The Arabs: A History. 1 edition. New York: Basic Books.

Ross, Michael L. 2015. "What Have We Learned about the Resource Curse?" Annual Review of Political Science 18 (1): 239-59. https://doi.org/10.1146/annurev-polisci-052213-040359.

Rotberg, R.I. 2010. When States Fail: Causes and Consequences.

Rothstein, Bo. 2011. The Quality of Government: Corruption, Social Trust, and Inequality in International Perspective. University of Chicago Press.

Sana Center for Strategic Studies. 2018. “Corruption in Yemen's War Economy.” Policy Brief 9. Sana'a, Yemen: Sana Center for Strategic Studies.

Schayegh, Cyrus. 2017. The Middle East and the Making of the Modern World. Cambridge, Massachusetts: Harvard University Press.

Scheele, Dr Judith. 2012. Smugglers and Saints of the Sahara: Regional Connectivity in the Twentieth Century. Cambridge: Cambridge University Press.

Scheele, Judith, and James McDougall, eds. 2012. Saharan Frontiers : Space and Mobility in Northwest Africa. Indiana University Press. Y. Bloomington, Ind. 
Schlumberger, Oliver, ed. 2007. Debating Arab Authoritarianism: Dynamics and Durability in Nondemocratic Regimes. 1 edition. Stanford, Calif: Stanford University Press.

Schneckener, Ulrich. 2004. States at Risk - Fragile Staaten Als Sicherheits- Und Entwicklungsproblem. Berlin: Stiftung Wissenschaft und Politik.

Soto Bermant, Laia. 2015. "The Myth of Resistance: Rethinking the 'Informal' Economy in a Mediterranean Border Enclave.” Journal of Borderlands Studies 30 (2): 263-78. https://doi.org/10.1080/08865655.2015.1046993.

Timmis, Hannah. 2017. "Formalising Informal Trade in North Africa." K4D Helpdesk Report. Brighton, UK: Institute of Development Studies.

Titeca, Kristof. 2012. "Tycoons and Contraband: Informal Cross-Border Trade in West Nile, NorthWestern Uganda." Journal of Eastern African Studies 6 (1): 47-63. https://doi.org/10.1080/17531055.2012.664703.

Titeca, Kristof, and Tom de Herdt. 2010. "Regulation, Cross-Border Trade and Practical Norms in West Nile, North-Western Uganda." Africa 80 (04): 573-594. https://doi.org/10.3366/afr.2010.0403.

Verme, Paolo, Branko Milanović, Sherine H. Al-Shawarby, Sahar El Tawila, and May Gadallah, eds. 2014. Inside Inequality in the Arab Republic of Egypt: Facts and Perceptions across People, Time, and Space. A World Bank Study. Washington, DC: World Bank.

Zartman, I. William. 2017. "States, Boundaries and Sovereignty in the Middle East: Unsteady but Unchanging." International Affairs 93 (4): 937-48. https://doi.org/10.1093/ia/iix118. 


\section{Notes}

${ }^{1}$ By some estimates the IS has been making between $\$ 1$ and $\$ 1.4$ million per day from oil smuggling through the two fields, Ajeel and Hamrin-2, making cross-border informality a central security issue.

http://www.chathamhouse.org/expert/comment/15203

${ }^{2}$ Some examples in the policy literature here include: Timmis 2017; Hanlon and Herbert 2015; International Crisis Group 2013.

${ }^{3}$ We define MENA to include Algeria, Bahrain, Egypt, Iran, Iraq, Israel, Jordan, Kuwait, Lebanon, Libya, Morocco, Oman, Palestine, Qatar, Saudi Arabia, Syria, Tunisia, Turkey the United Arab Emirates and Yemen. In engaging with some of the literature on the region, we at times refer to the region's Arab countries or states, which we define as the same group without Iran, Turkey and Israel. (

${ }^{4}$ Although informal trade does not feature in their analysis.

${ }^{5}$ A 2013 study on Tunisia found that informal cross-border trade was equivalent to more than half of its official trade with Libya, and more than its entire official trade with Algeria (Ayadi et al 2013).In Iran, the size of smuggling in 2007 was estimated to lie in the broad range of 6 to 25 percent of total trade (Farzanegan 2007). A recent study for the Algeria-Mali corridor suggests that formal trade pales in comparison to the thriving informal trade across the border. For Algeria the formal cross-border trade between the two countries was equivalent to only $1.2 \%$ of the informal trade (Bensassi et al. 2015).

${ }^{6}$ On Northern Mali, this point is eloquently made by Scheele (2012)

${ }^{7}$ A particularly colourful example of this trade was uncovered early in 2016, when customs officials stopped a shipment of 48,000 cans of Heineken beer disguised as Pepsi cans.

${ }^{8}$ In a security council statement in 2012, UN Secretary General Ban Ki-Moon said of the flows of goods through porous borders: "Such illicit flows undermine State sovereignty. They are threats to peace and security." (SC/10624, 25 April 2012)

${ }^{9}$ Although in the empirical context of sub-Saharan Africa, Meagher (2014) also provides an excellent introduction into changing discourses and framings of smuggling in academic and policy literatures.

${ }^{10}$ The list of failed state indicators drawn up by Rotberg's lists "smuggling" alongside "civil wars characterised by enduring violence", or "cessation of functioning legislatures" (2010, 5-9). Similarly, in Schneckener's work on the subject (2004), smuggling features as one of the main 'risk areas'.

${ }^{11}$ This mirrors the trend in Africa where falling trade barriers were actually associated with robust informal trading activity (Meagher 2003).

${ }^{12}$ See Gallien 2018a, Assaad 2014

${ }^{13}$ See Joffe (2007) for a detailed elaboration of the Algerian case.

${ }^{14}$ See for example: Boone (1994), Titeca (2012), Raeymaekers (2014)

${ }^{15}$ As Hanlon and Herbert (2015: p. 40) note: "Corruption was pervasive in the Ben Ali security apparatus, involving entire networks of customs agents, police officers, and senior officials. During that time, the lion's share of the proceeds from bribes and other illicit activities — as much as 80 percent—-went to Ben Ali and his immediate family".

${ }^{16}$ See World Bank (2014), Eibl and Malik (2016)

${ }^{17}$ See Haddad (2012) for a detailed discussion on this.

${ }^{18}$ See Boughzala and Hamdi (2014), Verme et al. (2014), Hibou (2011), Anderson (1987)

${ }^{19}$ Ayadi et al. 2013: "In the Libya-Tunisia corridor, informal trade is one of the largest employers in the region analyzed, if not the largest. Majority of those involved in the trade are local residents. Most are young men, with primary or secondary education and four dependents on average. Their income puts most of them under the Tunisian national poverty threshold". Ben Hassan (2013) quotes a resident in Morocco as saying: "There are very few job opportunities, and only a few people from my region finish university. This is our only way of providing a sustainable life".

${ }^{20}$ See Huesken (2018), Ellis (2018)

${ }^{21}$ For a detailed treatment on the subject, see Khan (2010).

22 The ISIS in Syria, Iraq, and Libya is reported to have derived its revenues from control over informal economy, especially the smuggling of oil and consumption goods.

${ }^{23}$ See Gallien 2019 for an extensive discussion of these two case studies and their ability to challenge mainstream conceptions of informal institutions in political economy.

${ }^{24}$ On the transfer of business models between formal and informal economic spheres, see also: (Meagher 2018) 
${ }^{25}$ It can also provide important 'reality-checks' to more economistic approaches, and new strategies for data collection and comparison. 